\title{
Time Value of Money dalam Perspektif Hukum Islam
}

\author{
Rahmat Ilyas
}

\begin{abstract}
Time Value of Money in the Perspective Islamic Law. This article reveals the Islamic view of the concept of Time Value of Money (referred by economists as positive time preference). This concept states that the value of commodities at present is higher than in the future. Time Value of Money is closely linked to the 'discount' concept that exists in capital and investment theory and, in practice, is used as a tool for project evaluation as well as investment decisions. This study concludes that Islam is not familiar with the concept of Time value of money. Islam only recognizes the concept of economic value of time. In Islamic view, money is simply a means of exchange, not a commodity. Similarly, the motive for money demand is to meet the needs of transaction, not for speculation.
\end{abstract}

Keywords: time value of money, Islamic law

\begin{abstract}
Abstrak: Time Value of Money dalam Perspektif Hukum Islam. Artikel ini mengulas pandangan Islam tentang konsep Time Value of Moneyatau juga yang sering disebut ekonom sebagai positive time preference. Konsep ini menyebutkan bahwa nilai komoditi pada saat sekarang lebih tinggi nilainya bila dibandingkan di masa mendatang. Time Value of Money sangat terkait erat dengan konsep 'diskonto' yang ada dalam teori modal dan investasi, dan secara praktis, digunakan sebagai alat evaluasi proyek maupun keputusan investasi. Hasil penelitian menyimpulkan bahwa Islam tidak mengenal konsep time value of money. Islam hanya mengenal konsep economic value of time. Dalam pandangan Islam, uang hanyalah sebagai alat tukar, bukan sebagai barang dagangan (komoditas). Begitu pula, motif permintaan akan uang adalah untuk memenuhi kebutuhan transaksi bukan untuk spekulasi.
\end{abstract}

Kata Kunci: time value of money, hukum Islam

Jurusan Syariah dan Ekonomi Islam Sekolah Tinggi Agama Islam Negeri Syaikh Abdurrahman Siddik Bangka Belitung, Jl. Raya Petaling KM.13 Desa Petaling Kec. Mendo Barat Bangka Belitung

E-mail: mtd_82@yahoo.com 


\section{Pendahuluan}

Kemunculan dan perkembangan ekonomi Islam sebagai suatu bentuk sistem ekonomi melahirkan berbagai polemik dan pemikiran mengenai bagaimana bentuk dan formulasi konsep dan teori ekonomi Islam. Sistem ekonomi Islam adalah sistem ekonomi yang betul-betul berbeda dengan konsep ekonomi konvensional dan berdiri sendiri atau ada beberapa persamaan, salah satu yang menjadi perdebatan yaitu konsep uang dalam sistem ekonomi. ${ }^{1}$ Uang merupakan inovasi besar dalam peradaban perekonomian dunia, posisinya sangat strategis dalam sistem ekonomi, dan sulit digantikan variabel lainnya. Sepanjang sejarah keberadaannnya, uang memainkan peran penting dalam perjalanan kehidupan modern. Uang berhasil memudahkan dan mempersingkat waktu transaksi pertukaran barang dan jasa. Uang dalam sistem ekonomi memungkinkan perdagangan berjalan secara efisien. ${ }^{2}$

Pada awalnya fungsi uang masih pada fungsi utamanya sebagai alat tukar. Namun dalam perkembangannya fungsi utama itu mulai bergeser, dalam ekonomi sistem kapitalis fungsi uang selain sebagai alat tukar, uang juga dijadikan sebagai komoditas sehingga uang diperjual belikan layaknya sebagai suatu komoditas. Dalam konsep keuangan modern yang diajarkan oleh kaum kapitalis dan sosialis, uang menjadi objek perdagangan. Dalam konsep keuangan modern, perdagangan uang merupakan instrumen penting dalam sistem perekonomian. Inilah yang menjadi perdebatan dalam sistem ekonomi Islam, bagaimana fungsi uang yang sesungguhnya. Apakah uang hanya berfungsi sebagai alat tukar, sebagaimana fungsi uang pada masa awalnya ataukah uang bisa dianggap sebagai komoditi yang bisa diperjualbelikan.

${ }^{1}$ Terkait perdebatan konsep uang dalam system ekonomi terdapat dalam beberapa tulisan di antaranya Santi Endriani. "Konsep Uang: Ekonomi Islam VS Ekonomi Konvensional." Anterior Jurnal 15, no. 1 (2015): h. 70-75. Ahmad Mansur. "Konsep Uang dalam Perspektif Ekonomi Islam dan Ekonomi Konvensional." Al-Qanun: Jurnal Pemikiran dan Pembaharuan Hukum Islam 12, no. 1 (2009): h. 155-179. Rahmat Ilyas. "Konsep Uang dalam Perspektif Ekonomi Islam." BISNIS: Jurnal Bisnis dan Manajemen Islam 4, no. 1 (2016): h. 35-57. Aam Selamet Rusydiana. "Relevansi Konsep Mata Uang Islami dengan Realita Ekonomi Modern.” Jurnal Manajemen Bisnis Syariah 7, no. 0 (2010): 01. Anita Rahmawaty. "Uang dan Kebijakan Moneter dalam Perspektif Ekonomi Islam." Jurnal Equilibrium 1, no. 2 (2013).

${ }^{2}$ Untuk lebih lengkapnya mengenai uang bisa dilihat dalam karya Manginar Manullang, Pengantar Teori Ekonomi Moneter (Deli: Deli Pertjetakan \& Toko Buku, 1962). 


\section{Pandangan Islam Tentang Uang}

Dalam ekonomi Islam, secara etimologi uang berasal dari kata alnaqdu-nuquid. Pengertiannya ada beberapa makna, yaitu al-naqdu yang berarti yang baik dari dirham, menggenggam dirham, dan al-naqdu juga berarti tunai. Kata nuquid tidak terdapat dalam Alquran dan hadis karena bangsa Arab umumnya tidak menggunakan nuqûd untuk menunjukkan harga. Mereka menggunakan kata dinar untuk menunjukkan mata uang yang terbuat dari emas dan kata dirham untuk menunjukkan alat tukar yang terbuat dari perak. Mereka juga menggunakan wariq untuk menunjukkan dirham perak, kata 'ain untuk menunjukkan dinar emas. Sementara itu kata fulus (uang tembaga) adalah alat tukar tambahan yang digunakan untuk membeli barang-barang murah. ${ }^{3}$

Definisi nuqûd menurut Abû Ubaid (wafat $224 \mathrm{H}$ ), dirham dan dinar adalah nilai harga sesuatu sedangkan segala sesuatu tidak bisa menjadi harga bagi keduanya, ini berarti dinar dan dirham adalah standard ukuran yang dibayarkan dalam transaksi barang dan jasa. Al-Ghazali (wafat 505 H) menyatakan, Allah menciptakan dinar dan dirham sebagai hakim penengah di antara seluruh harta sehingga seluruh harta bisa bisa diukur dengan keduanya. Ibn al-Qayyim (wafat $751 \mathrm{H}$ ) berpendapat, dinar dan dirham adalah nilai harga barang komoditas. Ini mengisyaratkan bahwa uang adalah standard unit ukuran untuk nilai harga komoditas. ${ }^{4}$

Pada dasarnya Islam memandang uang hanya sebagai alat tukar, bukan sebagai barang dagangan (komoditas). Oleh karena itu motif permintaan akan uang adalah untuk memenuhi kebutuhan transaksi (money demand for transaction), bukan untuk spekulasi. Islam juga sangat menganjurkan penggunaan uang dalam pertukaran karena Rasulullah telah menyadar kelemahan dari saah satu bentuk pertukaran di zaman dahulu yaitu barter (ba’i al-muqayyadah), dimana barang-barang saling dipertukarkan.

Menurut Afzalur Rahman, Rasulullah Saw. menyadari akan kesulitankesulitan dan kelemahan-kelemahan sistem pertukaran ini, lalu beliau

${ }^{3}$ Rozalinda, Ekonomi Islam: Teori dan Aplikasinya pada Aktivitas Ekonomi (Jakarta: PT Raja Grafindo Persada, 2014), h. 279.

${ }^{4}$ Ahmad Hasan, Mata Uang Islami: Telaah Komprehensif Sistem Keuangan Islami, trans. oleh Saifurrahman Barito (Jakarta: PT Raja Grafindo Persada, 2005), h. 5-8. 
ingin menggantinya dengan sistem pertukaran melalui uang. Oleh karena itu beliau menekankan kepada para sahabat untuk menggunakan uang dalam transaksi-transaksi mereka" ${ }^{5}$

Dalam konsep Islam tidak dikenal dengan money demand for speculation, karena spekulasi tidak diperbolehkan. Kebalikan dari sistem konvesional yang memberikan bunga atas harta, Islam malah menjadikan harta sebagai objek zakat. Uang adalah milik masyarakat sehingga menimbun uang di bawah bantal (dibiarkan tidak produktif) dilarang, karena hal itu berarti mengurangi jumlah uang yang beredar di masyarakat. Dalam pandangan Islam, uang adalah flow concept, sehingga harus berputar dalam perekonomian. Semakin cepat uang berputar dalam perekonomian, maka akan semakin tinggi tingkat pendapatan masyarakat dan semakin baik perekonomian. ${ }^{6}$

Syaikh Taqyuddin al-Nabhani menyatakan Islam telah memberikan kebebasan kepada manusia untuk melakukan pertukaran dengan mempergunakan apa saja yang dia sukai. Hanya saja, pertukaran barang dengan satuan uang tertentu itu telah ditunjukkan oleh Islam, di mana Islam telah menunjukkan satuan uang tersebut. ${ }^{7}$ Islam telah menetapkan bagi kaum muslimin kepada jenis tertentu yaitu emas dan perak. Kesimpulan ini berdasarkan beberapa alasan berikut: ${ }^{8}$

1. Islam telah menetapkan bagi kaum muslimin kepada jenis tertentu yaitu emas dan perak.

2. Islam mengharamkan menimbun (al-kanz) emas dan perak. Larangan tersebut tertuju kepada penimbun emas dan perak, sebagai emas dan perak, dan sebagai mata uang dan alat tukar.

3. Rasulullah Saw. telah menetapkan emas dan perak sebagai mata uang, dan menjadikan hanya emas dan perak sajalah sebagi standard uang, di mana standard barang dan jasa akan dikembalikan kepada standard tersebut.

${ }^{5}$ Afzalur Rahman, Doktrin Ekonomi Islam, 2 (Yogyakarta: PT. Dana Bhakti Wakaf, 1995), h. 73.

${ }^{6}$ Zainul Arifin, Dasar-dasar Manajemen Bank Syariah (Jakarta: Alvabeta, 2006), h. 16.

7 Taqyuddin al-Nabhani, Membangun Sistem Ekonomi Alternatif Persepektif Islam, Cet.VIII (Surabaya: Risalah Gusti, 2009), h. 297.

${ }^{8}$ Veithzal Rivai dan Andi Buchari, Islamic Economics (Jakarta: PT Bumi Aksara, 2009), h. 299. 
4. Ketika Allah Swt. mewajibkan zakat uang, maka Allah telah mewajibkan zakat tersebut untuk emas dan perak, kemudian Allah menentukan nishāb zakat tersebut dengan nishāb emas dan perak.

5. Ketika Islam menetapkan hukum pertukaran uang (sharf), Islam menetapkan uang dalam bentuk emas dan perak. Sharf adalah menukarkan atau membeli uang dengan uang, baik dalam jenis yang sama seperti membeli emas dengn emas atau perak dengan perak, maupun antar jenis yang berbeda seperti membeli emas dan perak.

Dalam sejarah Islam, uang adalah hasil adopsi dari peradaban Romawi dan Persia. Ini dimungkinkan karena penggunaan dan konsepnya tidak bertentangan dengan ajaran Islam. Dinar adalah mata uang yang diambil dari Romawi dan dinar adalah mata uang perak warisan Persia. ${ }^{9}$ Dalam Alquran, kedua logam ini dijelaskan fungsinya sebagai mata uang atau sebagai harta kekayaan yang disimpan. Hal ini dijelaskan dalam firman Allah Swt. dalam Q.s. al-Tawbah [9]: 34 yang berbunyi:

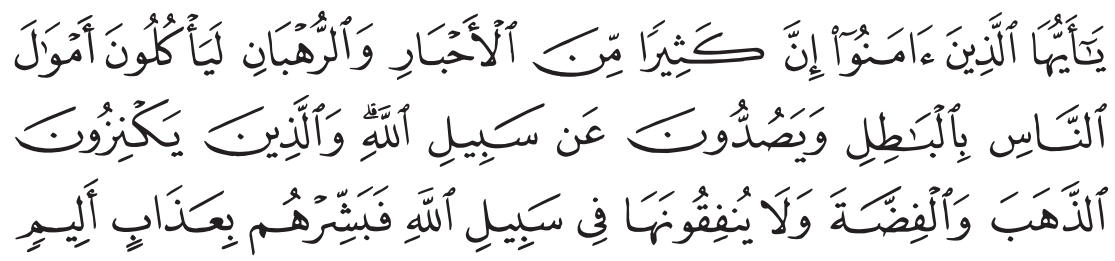

Hai orang-orang yang beriman, Sesungguhnya sebahagian besar dari orang-orang alim Yahudi dan rahib-rahib Nasrani benar-benar memakan harta orang dengan jalan batil dan mereka menghalang-halangi (manusia) dari jalan Allah. dan orang-orang yang menyimpan emas dan perak dan tidak menafkahkannya pada jalan Allah, Maka beritahukanlah kepada mereka, (bahwa mereka akan mendapat) siksa yang pedih.

\section{Fungsi Uang dalam Pandangan Islam Uang Sebagai Ukuran Harga}

Fungsi ini termasuk yang utama dan terpenting dari fungsi uang, karena itu para ahli ekonomi semestinya mengutamakan fungsi ini dalam

9 Abdullah al-Muslih dan Shalah Ash-Shawi, Fikih Ekonomi Keuangan Islam, trans. oleh Abu Umar Basyir (Jakarta: Darul Haq, 2004), h. 449. 
definisi uang yang berdasarkan pandangan terhadap fungsi-fungsinyasecara ekonomi dari seluruh fungsi-fungsi lain.Uang adalah standard ukuran harga, yakni sebagai media pengukur nilai harga komoditi dan jasa, dan perbandingan harga setiap komoditas dengan komoditas lainnya. Pada sistem barter sangat sulit untuk mengetahui harga setiap komoditas terhadap komoditas lainnya. ${ }^{10}$

Uang dalam fungsinya sebagai standar ukuran umum harga berlaku untuk ukuran nilai dan harga dalam komoditi, sepertiberlakunya standard meter untuk ukuran jarak, atau ampere untuk mengukur tegangan listrik, atau kilogram sebagai standard timbangan atau kubik sebagai ukuran volume (isi). ${ }^{11}$

Al-Sya’bi mengemukakan bahwa dia berpendapat dinar dan dirham itu adalah sebagai alat transaksi dan harga bagi setiap barang. Sebaliknya, tidak boleh seluruh barang (apa pun bentuknya) dijadikan sebagai alat transaksi dan harga untuk membeli emas dan perak. ${ }^{12}$ Sedangkan Ibn Rusyd $^{13}$ menyatakan bahwa, ketika seseorang susah menemukan nilai persamaan antar barang-barang yang berbeda, jadikan dinar dan dirham untuk mengukurnya. Apabila seseorang menjual kuda dengan beberapa baju, nilai harga kuda itu terhadap beberapa kuda adalah nilai harga baju itu terhadap beberapa baju. Maka jika kuda itu bernilai 50, tentunya baju-baju juga harus bernilai 50 .

\section{Uang Sebagai Media Transaksi}

Uang adalah alat tukar yang digunakan setiap individu untuk pertukaran komoditas dan jasa. Misalnya seseorang yang memiliki apel dan

${ }^{10}$ Ahmad Hasan, Mata UangIslami: Telaah Komprehensif Sistem Keuangan Islami, 12.

${ }^{11}$ Ahmad Hasan, 13.

${ }^{12}$ Abû 'Ubaid al-Qasim, Ensiklopedia Keuangan Publik, trans. oleh Setiawan Budi Utomo (Jakarta: Gema Insani Press, 2009), 523.

${ }^{13}$ Ibn Rusyd merupakan tokoh Islam mewarnai banyak pemikiran lintas disipilin ilmu. Telah banyak tulisan yang telah membahas pemikirannya, terkait persoalan ekonomi, pemikiran Ibn Rusyd telah banyak menuliskannya, di antaranya Rela Diwanti. "Pemikiran Ibnu Rusyd Tentang Qiradh dan Implikasinya dengan Produk Qiradh Pada Bank Riau Syariah Cabang Pekanbaru." PhD diss., Universitas Islam Negeri Sultan Syarif Kasim Riau, 2010. Dian Asriani Lubis. "Kepailitan Menurut Ibnu Rusyd dan Perbandingannya dengan Hukum Kepailitan Indonesia." PhD diss., Universitas Islam Negeri Sultan Syarif Kasim Riau, 2011. 
membutuhkan beras, kalau dalam sistem barter pemilik apel berangkat ke pasar untuk menemukan orang yang memiliki beras dan membutuhkan apel sehingga bisa terjadi pertukaran antar keduanya. Ketika orang-orang sudah membuat uang, pemilik apel dapat menjual barangnya dengan imbalan uang kemudian dengan uang itu ia bisa membeli beras. Demikian juga pemilik beras dapat menjual berasnya dengan uang dan dengan uang itu ia dapat membeli apa saja barang dan jasa yang ia kehendaki.

Uang menjadi media transaksi yang sah yang harus diterima oleh siapapun bila ia ditetapkan oleh negara. Inilah perbedaan uang dengan media transaksi lain seperti cek. Cek juga berlaku sebagai alat pembayaran karena penjual dan pembeli sepakat menerima cek sebagai alat bayar. ${ }^{14}$

\section{Uang Sebagai Penyimpan Nilai}

Uang berfungsi sebagai penyimpan nilai, hal ini seperti yang diisyaratkan oleh Ibn Khaldun, uang sebagai alat simpanan, ia menyatakan, kemudian Allah menciptakan dari barang tambang, emas dan perak sebagai nilai dari setiap harta. Dua jenis ini merupakan simpanan dan perolehan orang-orang di dunia kebanyakan.

Dari ketiga fungsi tersebut jelaslah bahwa yang terpenting adalah stabilitas uang, bukan bentuk uang itu sendiri, uang dinar yang terbuat dari emas dan diterbitkan oleh raja Dinarius dari kerajaan Romawi memenuhi kriteria uang yang nilainya stabil. Begitu pula uang dirhan yang terbuat dari perak dan diterbitkan oleh ratu dari kerajaan Sasanid Persia juga memenuhi kriteria uang yang stabil. Sehingga, meskipun dinar dan dirham yang diterbitkan oleh bukan negara Islam, keduanya dipergunakan di zaman Rasulullah. ${ }^{15}$

Uang dalam ekonomi Islam adalah sesuatu yang bersifat flow concept bukan stock concept. Uang harus selalu mengalir, beredar di kalangan masyarakat dalam kehidupan ekonomi. Teori ekonomi Islam ini di kemudian hari muncul dengan teori Irfing Fisher bahwa:

\footnotetext{
${ }^{14}$ Adiwarman A Karim, Ekonomi Makro Islami (Jakarta: PT Raja Grafindo Persada, 2007), h. 81.

15 Adiwarman A Karim, Ekonomi Makro Islami, h. 82.
} 


$$
\begin{aligned}
& \mathrm{MV}=\mathrm{PT} \\
& \mathrm{M}=\text { jumlah uang } \\
& \mathrm{V}=\text { tingkat perputaran uang } \\
& \mathrm{P} \quad=\text { tingkat harga barang } \\
& \mathrm{T} \quad=\text { jumlah barang yang diperdagangkan }
\end{aligned}
$$

Persamaan ini mengemukakan semakin cepat perputaran uang, maka semakin besar income yang diperoleh. Untuk itu Islam menolak pendapat yang menyatakan, uang bersifat stock concept. Kekayaan atau kapital adalah private goods atau benda-benda milik pribadi yang hanya beredar pada individu tertentu saja. Uang adalah public goods benda-benda yang dimiliki oleh semua orang dan harus beredar pada semua orang. ${ }^{16}$

\section{Time Value of Money dalam Ekonomi Konvensional}

Konsep time value of money ${ }^{17}$ atau juga disebut ekonom sebagai

${ }^{16}$ Rozalinda, Ekonomi Islam: Teori dan Aplikasinya pada Aktivitas Ekonomi, h. 294.

${ }^{17}$ Terkait time value of money, beberapa artikel spesifik membahas hal tersebut di antaranya Hui-Ming Wee, and Sh-Tyan Law. "Replenishment and Pricing Policy for Deteriorating Items Taking Into Account the Time-Value of Money." International Journal of Production Economics 71, no. 1-3 (2001): h. 213-220. T. K. Datta, and A. K. Pal. "Effects of Inflation and TimeValue of Money on an Inventory Model with Linear Time-Dependent Demand Rate and Shortages." European Journal of Operational Research 52, no. 3 (1991): h. 326-333. Hui-Ming Wee, and Sh-Tyan Law. "Economic Production Lot Size for Deteriorating Items Taking Account of the Time-Value of Money." Computers \& Operations Research 26, no. 6 (1999): h. 545-558. M. Jeya Chandra, and Michael L. Bahner. "The Effects of Inflation and the Time Value of Money on Some Inventory Systems." International Journal of Production Research 23, no. 4 (1985): h. 723-730. Bhaba R. Sarker, and Haixu Pan. "Effects of Inflation and the Time Value of Money on Order Quantity and Allowable Shortage." International Journal of Production Economics 34, no. 1 (1994): h. 65-72. Jayanta Kumar Dey, Shyamal Kumar Mondal, and Manoranjan Maiti. "Two Storage Inventory Problem with Dynamic Demand and Interval Valued Lead-Time Over Finite Time Horizon Under Inflation and Time-Value of Money." European Journal of Operational Research 185, no. 1 (2008): h. 170-194. Biswajit Sarkar, Shib Sankar Sana, and Kripasindhu Chaudhuri. "An Imperfect Production Process for Time Varying Demand with Inflation and Time Value of Money-an EMQ Model." Expert Systems with Applications 38, no. 11 (2011): h. 13543-13548. K-L. Hou, and L-C. Lin. "An EOQ Model for Deteriorating Items with Priceand Stock-Dependent Selling Rates Under Inflation and Time Value of Money." International Journal of Systems Science 37, no. 15 (2006): h. 1131-1139. M. Fahim Khan. "Time Value of Money and Discounting in Islamic Perspective." Review of Islamic Economics 1, no. 2 (1991): h. 35-45. Nita H. Shah. "Inventory Model for Deteriorating Items and Time Value of Money for a Finite Time Horizon Under the Permissible Delay in Payments." International Journal of Systems Science 37, no. 1 (2006): h. 9-15. Horng-Jinh Chang, Cheng-Hsing Hung, and Chung-Yuan Dye. "A Finite Time Horizon Inventory Model with Deterioration and Time-Value 
positive time preference menyebutkan bahwa nilai komoditi pada saat ini lebih tinggi nilainya bila dibandingkan di masa mendatang. Time Value of Money sangat terkait erat dengan konsep 'diskonto' yang ada dalam teori modal dan investasi. Secara praktis, digunakan sebagai alat evaluasi proyek maupun keputusan investasi. Misalnya, Net Present Value (NPV), Cost Benefit Analisys, Internal Required Rate of Return, Deviden Modal dalam assetvaluation. ${ }^{18}$ Diskonto dalam positif time preference biasanya didasarkan pada, atau paling tidak berhubungan intim, tingkat bunga (interestrate). ${ }^{19}$ Sedangkan dalam ekonomi Islam, bunga dipandang sebagai riba, yang secara tegas dilarang oleh Islam.

Menurut Adiwarman A. Karim dalam Muhammad, konsep Time Value of Money pada dasarnya merupakan intervensi konsep biologi dalam bidang ekonomi. Konsep Time Value of Money muncul karena adanya anggapan bahwa uang disamakan dengan barang yang hidup (sel hidup). Sel yang hidup, untuk satuan waktu dapat menjadi lebih besar dan berkembang. Pertumbuhan sel dalam ilmu biologi diformulasikan dengan rumus sebagai berikut $\mathrm{Pb}=\mathrm{P} 0(1+\mathrm{g}) \mathrm{t}^{20}$

Dimana: $\mathrm{Pb}=$ Pertumbuhan

$$
\begin{aligned}
& \mathrm{P} 0=\text { Sel pada awalnya } \\
& \mathrm{g}=\text { Pertumbuhan } \\
& \mathrm{t}=\text { Waktu }
\end{aligned}
$$

Formula ini kemudian diadopsi melalui ilmu keuangan akibatnya, anggapan uang sebagai sesuatu yang hidup terjadi. Dari formula tersebut,

\footnotetext{
of Money Under the Conditions of Permissible Delay in Payments." International Journal of Systems Science 33, no. 2 (2002): h. 141-151. Abu Umar Faruq Ahmad, and M. Kabir Hassan. "The Time Value of Money Concept in Islamic Finance." American Journal of Islamic Social Sciences 23, no. 1 (2006): h. 66. S. R., Neeraj Kumar Singh, and Rachna Kumari. "Two-Warehouse Inventory Model for Deteriorating Items with Shortages Under Inflation and Time-Value of Money." International Journal of Computational and Applied Mathematics 4, no. 1 (2009): h. 83-94. Madhab Mondal, Amit Kumar Maity, Manas Kumar Maiti, and Manoranjan Maiti. "A Production-Repairing Inventory Model with Fuzzy Rough Coefficients Under Inflation and Time Value of Money." Applied Mathematical Modelling 37, no. 5 (2013): h. 3200-3215.

${ }^{18}$ Muhamad, Dasar-dasar Keuangan Islam (Yogyakarta: Ekonosia, 2011), h. 92.

${ }^{19}$ Iggi H Achsien, Investasi Syariah di Pasar Modal: Menggagas Konsep dan Praktek Manajemen Portofolio Syariah (Surakarta: Gramedia Pustaka Utama, 2009), h. 45.

${ }^{20}$ Muhammad, Manajemen Bank Syariah (Yogyakarta: UPP AMP YKPN, 2005), h. 48.
} 
akhirnya dirumuskan sebagai berikut $: F V=P V(1+i) n^{21}$

Dimana:

$\mathrm{FV}=$ FutureValue(nilai uang di masa akan datang)

$\mathrm{PV}=$ PresentValue (nilai uang masa sekarang)

$\mathrm{i} \quad=$ Tingkat suku bunga

$\mathrm{n}$ = Waktu.

Konsep time value of money dalam kaitannya dengan analisis modal dan investasi, maka disajikan secara bersama dengan cost of capital, pembahasan mengenai kedua persoalan ini (modal dan investasi), tidak dapat dipisahkan dengan konsep diskonto. Menurut Iggi, konsep diskonto sangat penting dalam analisis teori modal dan investasi. Secara praktis digunakan dalam evaluasi proyek atau pun keputusan invesatasi, misalnya model net present value (NPV), cost benefit analysis, internal required rate of return (IRR), deviden model dalam asset valuation, dan seterusnya. Diskonto inilah yang dimaksud denganTime Value of Money. ${ }^{22}$

Konsep Time Value of Money atau yang disebut ekonom sebagai positive time preference menyebutkan bahwa nilai komoditi pada saat ini lebih tinggi di banding nilainya di masa depan. Diskonto dalam positif time preference ini biasanya didasarkan pada atau paling tidak berhubungan erat dengan bunga (interest rate). Sehingga bunga berfungsi sebagai alat ukur dalam penentuan nilai waktu modal dan investasi.

Sejak terjadinya konvergensi pendapat dalam fikih bahwa bunga diharamkan dalam Islam karena dianggap salah satu bentuk riba, muncullah pertanyaan-pertanyaan tentang penggunaan diskonto dalam evaluasi investasi, dan juga pemakainya sebagai cost of capital. Misalnya apakah penggunaannya secara mendasar bertentangan dengan prinsip dasar pelarangan riba tersebut.

Terdapat perbedaan pendapat dalam hal ini, yang berarti belum terdapat kesepakatan tetapi ada penyikapan yang cukup sama terhadap teori positive time preference yaitu bahwa teori tersebut tidak bisa diasumsikan

${ }^{21}$ Muhammad, Manajemen Bank Syariah, h. 48.

22 Iggi H Achsien, Investasi Syariah di Pasar Modal: Menggagas Konsep dan Praktek Manajemen Portofolio Syariah, h. 45. 
begitu saja diterima secara menyeluruh di kalangan ekonom. Menurut Muhammad Anas al-Zarqa, kalau disebut bahwa positive time preference (time value of money) merupakan pola yang wajar, dan normal dengan melihat latar historis, maka yang rasional justeru memungkinkan positif maupun negatif time preference, kemungkinan positif maupun negatif dan bahkan zero time preference adalah ketidakpastian di masadepan. ${ }^{23}$

Perbedaan pendapat terjadi pada saat suatu rate tertentu digunakan sebagai faktor diskonto. Satu sisi menganggap dilarang karena Islam tidak membolehkan riba, di lain pihak, ditemukan adanya praktik penjualan dalam bentuk bai' al-salam dan bai' mu'ajjal yang ternyata tidak dilarang dalam Islam. Dalam praktik penjualan yang demikian, harga-harga komoditi boleh berbeda dengan harga spot-nya dengan adanya perlibatan waktu dalam proses pertukarannya. Secara sederhana, terkadang ini dianggap bentuk pengakuan time value of money atau adanya tingkat diskonto. ${ }^{24}$

Shabir F. Ulgener membolehkan interest rate dipakai sebagai faktor diskonto. Katanya yang diperlukan adanya perbedaan interest rate dipakai sebagai suatu surplus (riba) dengan interest sebagai faktor perhitungan efesiensi ekonomi. Muhammad Anas al-Zarqa juga, menyebutkan diskonto didasari oleh prinsip oportunity cost untuk efesiensi, karena ekonom pun sepakat bahwa mengabaikan diskonto akan menyebabkan kehilangan efesiensi melalui pelarangan isräf (sesuatu yang berlebihan/waste). Hanya saja dalam hal ini, Muhammad Anas al-Zarqa tidak mau menggunakan interest rate sebagai faktor diskonto, karena kalau diskonto kemudian membuat interest (bunga) harus pula diterima, sudah semestinya demikian itu ditolak.

Sehubungan dengan hal di atas, maka yang dijadikan alternatif adalah rate of return dari aset yang beresiko, misalnya saham dengan menggunakan ukuran rasio earning per share dengan harga atau (E/P) hal

${ }^{23}$ Iggi H Achsien, Investasi Syariah di Pasar Modal: Menggagas Konsep dan Praktek Manajemen Portofolio Syariah, h. 45.

${ }^{24}$ Diskonto Bank, yaitu potongan yang diperhitungkan bank (biasanya dalam persen) atas suatu surat berharga karena pembayaran sebelum jatuh tempo (bank discount). LihatAhmad Ifham Sholihin, Buku Pintar Ekonomi Syariah (Jakarta: PT. Gramedia Pustaka Utama, 2010), 248. 
ini berangkat dari gagasan teori cost of capital oleh Modigliani dan Miller (MM), menyebutkan bahwa setiap aset memiliki "rate" yang berbeda-beda. Dengan demikian dapat disimpulkan bahwa pembolehan penggunaan rate tertentu sebagai faktor diskonto didasarkan pada alasan bahwa discount rate dan interest rate merupakan dua hal yang berbeda. Di samping itu faktor diskonto diperlukan secara definitif untuk kepentingan efesiensi.

Secara singkat pendapat yang membolehkan penggunaan rate tertentu sebagai faktor diskonto didasarkan pada alasan bahwa discount rate dan interest rate merupakan dua hal yang berbeda. Dan faktor diskonto ini diperlukan secara definitif untuk kepentingan efisiensi. ${ }^{25}$

Pendapat yang menentang penggunaan rate sebagai faktor diskonto disampaikan oleh M. Akram Khan. Ia menolak positive time preference, sebab penerimaan terhadap konsep ini dapat mendorong legitimasi interest (bunga) dan membuka pintu belakang bagi masuknya kembali riba. Sedangkan argumen tentang efisiensi ditentukan oleh faktor penentunya, misalnya proses manajerial, sehingga faktor diskonto bukan merupakan penentu suatu efesiensi. Terlebih, M. Akram Khan tidak menyebut opportunity cost yang dikandung oleh faktor diskonto sebagai cost of capital. ${ }^{26}$

\section{Kritik Terhadap Time Value Of Money}

Dalam teori ekonomi konvensional, time value of money didefinisikan sebagai "A dollar today is worth more than a dollar in the future because a dollar today can be invested to get a return. Definisi ini menurut Adiwarman Karim tidak akurat, karena setiap investasi selalu mempunyai kemungkinan untuk mendapatkan positif, negative atau no return. Itu sebabnya dalam teori finance, ada dua alasan dari teori konvensional terhadaptime value of money yaitu:

1. Presence of inflation. Katakalah tingkat inflasi $10 \%$ pertahun. Seseorang dapat membeli sepuluh potong goreng pisang hari ini

${ }^{25}$ Iggi H Achsien, Investasi Syariah di Pasar Modal: Menggagas Konsep dan Praktek Manajemen Portofolio Syariah, h. 47.

${ }^{26}$ Iggi H Achsien, Investasi Syariah di Pasar Modal: Menggagas Konsep dan Praktek Manajemen Portofolio Syariah, h. 47. 
dengan membayar sejumlah Rp. 10.000,-. Namun bila ia membelinya tahun depan, degan sejumlah uang yang sama, yaitu Rp. 10.000,ia hanya dapat membeli sembilan pisang goreng. Oleh karena itu ia akan meminta kompensasi untuk hilangnya daya beli uangnya akibat inflasi.

2. Preference present consumption to future consumption. Bagi umumnya individu, present consumtion lebih disukai daripada future consumtion. Katakanlah tingkat inflasi nihil, sehingga dengan uang Rp. 10.000,seseorang tetap dapat membeli sepuluh pisang goreng hari ini maupun tahun depan. Bagi kebanyakan orang, mengkonsumsi sepuluh pisang goreng hari ini lebih disukai daripada mengkonsumsi sepuluh pisang goreng tahun depan. Dengan argumentasi ini, meskipun suatu perekonomian tingkat inflasinya nihil, seseorang lebih menyukai Rp. 10.000,- hari ini dan mengkonsumsi hari ini. Oleh karena itu untuk menunda konsumsi ia meminta kompensasi. ${ }^{27}$

Beberapa ahli ekonomi berpendapat bahwa manusia pada dasarnya lebih mengutamakankehendaknya sekarang dibanding kehendaknya di masa depan. Manusia dianggap akan mengedepankan kepuasan untuk masa sekarang. Kalangan inilah yang menjelaskan fenomena bunga dengan rumusan yang dikenal dengan menurunnya nilai barang diwaktu mendatang dibanding dengan nilai barang diwaktu kini. Bhom-Bawerk, pendukung utama pendapat ini, menyebutkan tiga alasan mengapa nilai barang di waktu yang akan datang berkurang, yaitu sebagai berikut:

1. Keuntungan di masa mendatang diragukan (uncertainty). Hal demikian disebabkan ketidakpastian peristiwa yang melingkupi manusia di masa mendatang. Sedangkan keuntungan di saat sekarang sangat jelas dan pasti.

2. Kepuasan terhadap kehendak atau keinginan masa kini lebih bernilai bagi manusia daripada kepuasannya pada masa mendatang. Karena mungkin saja seseorang tidak memiliki kehendak seperti sekarang.

3. Kenyataannya barang-barang pada waktu kini lebih penting dan

${ }^{27}$ Adiwarman A Karim, Bank Islam: Analisis Figh dan Keuangan (Jakarta: PT Raja Grafindo Persada, 2006), h. 377. 
berguna. Dengan demikian barang-barang tersebut mempunyai nilai yang lebih tinggi di banding dengan barang-barang pada waktu yang akan datang. ${ }^{28}$

Dapat disimpulkan bahwa keuntungan sekarang lebih berharga dari pada keuntungan di masa mendatang. Modal sekarang lebih bernilai, daripada dipinjam dan dikembalikan satu tahun mendatang. Adanya bunga sebagai instrumennya lebih dimaksudkan sebagai nilai pembayar yang sama terhadap modal yang dipinjam semula.

\section{Time Value of Money dalam Pandangan Hukum Islam}

Persoalan riba sebetulnya sangat berkaitan dengan masalah uang. Sebagai perbandingan dengan teori ekonomi konvensional (kapitalisme), Islam membicarakan uang sebagai sarana penukar dan penyimpan nilai, tetapi uang bukanlah barang dagangan. Uang menjadi berguna hanya jika ditukar dengan benda yang nyata atau jika digunakan untuk membeli jasa.

Dalam Islam tidak dikenal dengan adanya time value of money, yang dikenal adalah economic value of time. Teori time value of time adalah sebuah kekeliruan besar karena mengambil dari ilmu pertumbuhan populasi dan tidak ada di ilmu finance. Dalam menghitung pertumbuhan populasi digunakan rumus:

$$
\mathrm{Pt}=\mathrm{Po}(1+\mathrm{r})
$$

Rumus ini kemudian diadopsi begitu saja dalam ilmu finance sebagai teori bunga majemuk menjadi:

$$
\mathrm{FV}=\mathrm{PV}(1+\mathrm{r})
$$

Jadi, future value dari uang dianalogikan dengan jumlah populasi tahun ke-t, present value dari uang dianalogikan dengan jumlah populasi tahun ke $=0$, sedangkan tingkat suku bunga dianalogikan dengan tingkat pertumbuhan populasi. Jadi hal ini keliru besar, karena uang bukanlah

${ }^{28}$ Muhammad Syafi'i Antonio, Bank Syariah dari Teori ke Praktik (Jakarta: Gema Insani Press, 2001), h. 74. 
mahkluk hidup yang dapat berkembang biak dengan sendirinya. ${ }^{29}$

Dalam ekonomi konvensional penerapan time value of money tidak senaif yang dibayangkan, misalnya dengan mengabaikan ketidakpastian return yang akan diterima. Bila unsur ketidakpastian return ini dimasukkan, ekonomi konvensional menyebut kompensasinya sebagai discount rate. Jadi discount rate lebih bersifat umum dibandingkan istilah interest rate. Dalam ekonomi konvensional, ketidakpastian return dikonversi menjadi suatu kepastian melalui premium for uncertainty. Dalam setiap investasi tentu selalu ada probabilitas untuk mendapat positive return, negative return, dan no return. Adanya probabilitas inilah yang menimbulkan ketidakpastian. Probabilitas untuk mendapatkan negative return dan no return yang dipertukarkan dengan sesuatu yang pasti yaitu premium for uncertainty.

Landasan atau keadaan yang digunakan oleh ekonomi konvensional inilah yang ditolak dalam ekonomi syariah, yaitu keadaan mendapatkan hasil tanpa memperhatikan suatu risiko (alghunmu bi al ghurni) dan memperoleh hasil tanpa mengeluarkan suatu biaya.

Dalam Islam, keuntungan bukan saja keuntungan di dunia, namun yang dicari adalah keuntungan di dunia dan akhirat. Oleh karenanya, pemanfaatan waktu itu bukan saja harus efektif dan efisien namun ia juga harus didasari keimanan. Keimanan inilah yang akan mendatangkan keuntungan di akhirat. Sebaliknya, keimanan yang tidak mampu mendatangkan keuntungan di dunia, berarti keimanan yang tidak diamalkan.

Dalam Alquran disebutkan nilai waktu, termasuk nilai ekonomi waktu ditentukan oleh keimanan, amal baik, saling mengingatkan dalam hal kebaikan dan kesabaran. Hal ini terkandung dalam firman Allah dalam Q.s. al-Ashr [103]: 1-3 yang berbunyi:

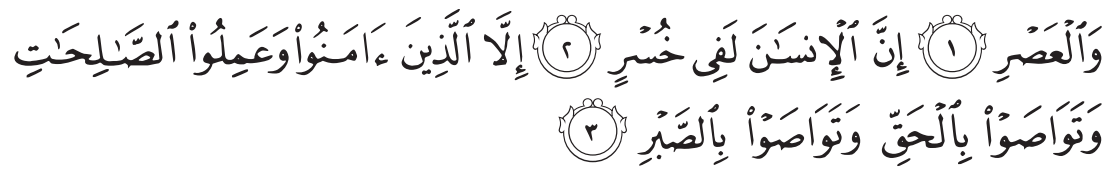

Demi masa. Sesungguhnya manusia itu benar-benar dalam kerugian, kecuali orang-orang yang beriman dan mengerjakan amal saleh dan

${ }^{29}$ Adiwarman A Karim, Ekonomi Makro Islami, h. 88. 
nasehat menasehati supaya mentaati kebenaran dan nasehat menasehati supaya menetapi kesabaran. ${ }^{30}$

Surah al-Ashr ini menunjukkan bahwa waktu bagi semua orang adalah sama kuantitasnya, yaitu 24 jam sehari, 7 hari dalam seminggu. Namun nilai dari waktu tersebut adalah tergantung pada bagaimana seseorang memanfaatkan waktu. Semakin efektif dan efisien, maka akan semakin tinggi nilai waktunya. Efektif dan efisien akan mendatangkan keuntungan didunia bagi siapa saja yang melaksanakannya. ${ }^{31}$

Waktu adalah modal utama manusia, apabila tidak diisi dengan kegiatan yang positif, akan berlalu begitu saja. Akan hilang dan ketika itu jangankan keuntungan yang diperoleh, modal pun telah hilang. Sayyidina Ali r.a. pernah berkata: "rezeki yang tidak diperoleh hari ini masih dapat diharapkan lebih dari itu diperoleh besok, tetapi waktu yang berlalu hari ini tidak mungkin dapat diharapkan kembali esok."32

Jika ditarik dalam konteks ekonomi, maka keuntungan adalah diperoleh setelah menjalankan aktivitas bisnis. Jadi barang yang siapa yang melakukan aktivitas bisnis secara efektif dan efisien, maka ia akan mendapatkan keuntungan.

Dalam konsep Islam tidak dikenal money demand for speculation. Hal ini karena spekulasi tidak diperbolehkan. Uang pada hakikatnya adalah milik Allah Swt. yang diamanahkan kepada manusia. Oleh karenanya, menimbun uang (dibiarkan tidak produktif) tidak dikehendaki karena berarti mengurangi jumlah uang beredar. Dalam pandangan Islam, uang adalah flow concept, karenanya uang harus selalu berputar dalam perekonomian, akan semakin tinggi tingkat pendapatan masyarakat maka akan semakin baik perekonomian.

Implikasi konsep time value of money adalah adanya bunga. Sedangkan bunga erat kaitannya dengan riba, dan riba adalah haram serta zulm. Agama melarangnya. Sehingga dianggap tidak sesuai dengan keadilan di mana "al-qhumu biqhurni" (mendapatkan hasil tanpa mengeluarkan

\footnotetext{
${ }^{30}$ Departemen Agama, Alquran dan Terjemahnya (Semarang: Asy-Syifa, 2000), h. 432.

${ }^{31}$ Muhammad, Manajemen Bank Syariah, h. 49.

${ }^{32}$ M. Quraish Shihab, Tafsir al-Misbah, 15, Cet. 5 (Jakarta: Lentera Hati, 2012), h. 585.
} 
risiko), dan "al-khraj bila dhaman" (memperoleh hasil tanpa mengeluarkan biaya). Hal ini didasarkan pada firman Allah Q.s. al-Baqarah [2]: 278 yang berbunyi:

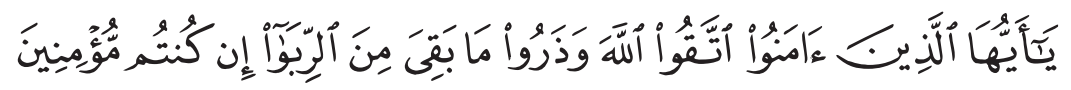

Hai orang-orang yang beriman, bertakwalah kepada Allah dan tinggalkan sisa Riba (yang belum dipungut) jika kamu orang-orang yang beriman. ${ }^{33}$

Adanya ijmak menentang bunga, mengantarkan pada pembicaraan tentang alternatif terhadap sistem intermediasi keuangan modern yang berbasis bunga. Sistem yang diajukan ini dimaksudkan .untuk lebih banyak mengandalkan pada modal sendiri (equity) dan sedikit pada kredit, yang terdiri dari kombinasi mode-mode primer seperti seperti mudhärabah (kemitraan pasif), musyärakah (kemitraan aktif), dan model-model sekunder seperti muräbahah (cost plus service charge), ijārah (sewa), ijārah wa iqtinä' (sewa-beli), salam (forward delivery contract), dan istisnā(contracted production). ${ }^{34}$

Dalam ajaran Islam, aktifitas bisnis tidak boleh dipastikan bahwa ia akan mendapatkan keuntungan di masa mendatang. Karena manusia tidak pernah tahu apa yang akan terjadi hari esok. Dalam bisnis seseorang akan menghadapi satu diantara tiga hal:positif return, negative return, bahkan no return. Hal ini didasarkan pada ayat Q.s. Luqman [31]: 34 yang berbunyi:

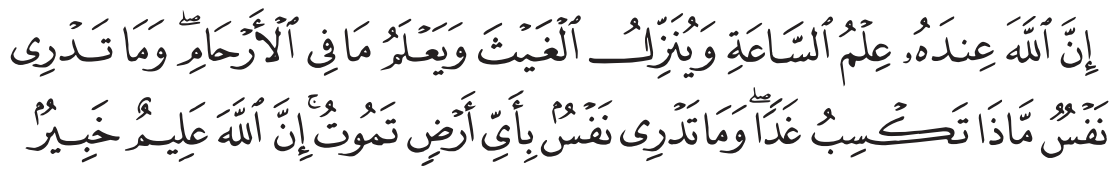

Sesungguhnya Allah, hanya pada sisi-Nya sajalah pengetahuan tentang hari Kiamat; dan Dia-lah yang menurunkan hujan, dan mengetahui apa yang ada dalam rahim. dan tiada seorangpun yang dapat mengetahui (dengan pasti) apa yang akan diusahakannya besok. dan

${ }^{33}$ Departemen Agama, Alquran dan Terjemahnya, h. 36.

${ }_{34}$ M. Umar Capra, Masa Depan Ilmu Ekonomi: Sebuah Tinjauan Islam (Jakarta: Gema Insani Press, 2001), h. 223. 
tiada seorangpun yang dapat mengetahui di bumi mana Dia akan mati. Sesungguhnya Allah Maha mengetahui lagi Maha Mengenal. ${ }^{35}$

Atas dasar ini maka aktifitas bisnis sebaiknya didasarkan pada mudharabah, musyarakah, maupun yang lain, yang tidak mengandung unsur kepastian, dimana keuntungan dibagi setelah usaha selesai. Oleh karena konsep time value of money tidak selaras dengan konsep ekonomi Islam, dan teori inilah yang menelurkan konsep bunga (interest) maka teori tersebut harus ditolak.

Dalam konteks hukum Islam, riba merupakan sesuatu yang sangat dilarang, karena bertentangan dengan ajaran agama dan prinsip keadilan. Beberapa ayat Alquran yang secara tegas melarang riba diantaranyaQ.s. Ali Imran [3]: 130:

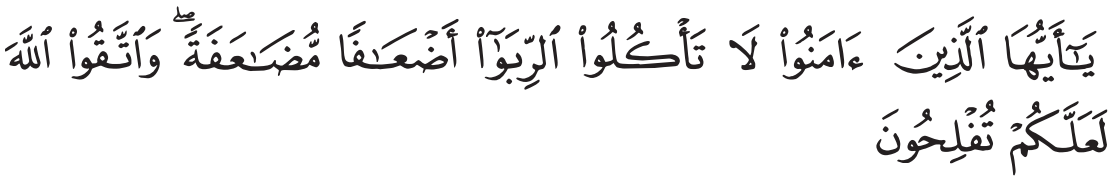

Hai orang-orang yang beriman, janganlah kamu memakan Riba dengan berlipat gandadan ${ }^{36}$ bertakwalah kamu kepada Allah supaya kamu mendapat keberuntungan. ${ }^{37}$

Selain itu juga dalam kaidah fikih disebutkan bahwa:

Apabila sesuatu yang mengandung unsur riba dipertukarkan antara keduanya, maka kesamaan dan penyerahan langsung merupakan syarat wajib. Akan tetapi apabila suatu barang ditukar dengan barang yang berbeda jenis, maka penyerahan langsung saja yang diwajibkan. Ketika sebabnya (illat) berbeda, maka kewajiban-kewajiban tadi menjadi tidak ada. ${ }^{38}$

${ }^{35}$ Departemen Agama, Alquran dan Terjemahnya, h. 331.

${ }^{36}$ Riba di sini ialah Riba nasi'ah. menurut sebagian besar ulama bahwa Riba nasi'ah itu selamanya haram, walaupun tidak berlipat ganda. Riba itu ada dua macam: nasiah dan fadhl. Riba nasiah ialah pembayaran lebih yang disyaratkan oleh orang yang meminjamkan. Riba fadhl ialah penukaran suatu barang dengan barang yang sejenis, tetapi lebih banyak jumlahnya karena orang yang menukarkan mensyaratkan demikian, seperti penukaran emas dengan emas, padi dengan padi, dan sebagainya. Riba yang dimaksud dalam ayat ini Riba nasi'ah yang berlipat ganda yang umum terjadi dalam masyarakat Arab zaman jahiliyah.

37 Departemen Agama, Alquran dan Terjemahnya, h. 33.

${ }^{38}$ Muhammad Tahir Mansoori dan Hendri Tanjung, Kaidah-kaidah Fiqih Keuangan dan 
Ada beberapa pendapat dalam menjelaskan riba, namun secara umum terdapat benang merah yang menegaskan bahwa riba adalah pengambilan tambahan, baik dalam transaksi jual beli maupun pinjam-meminjam secara batil atau bertentangan dengan prinsip muamalah. Namun yang dimaksud riba yaitu setiap penambahan yang diambil tanpa adanya satu transaksi pengganti atau penyeimbang yang dibenarkan dalam hukum Islam, dan yang dimaksud dengan transaksi pengganti yaitu transaksi bisnis atau komersial yang melegitimasi ada nya penambahan tersebut secara adil, seperti: transaksi jual beli, gadai, sewa, atau bagi hasil.

Banyak pendapat mengenai bunga, pertama alasan menahan diri (abstinence) yang menegaskan ketika kreditor menahan diri, ia menangguhkan keinginannya memanfaatkan uangnya sendiri semata-mata untuk memenuhi keinginan orang lain. Namun dalam kenyataannya kreditor hanya akan meminjamkan uang yang tidak ia gunakan sendiri atau uang yang berlebih dari yang ia perlukan dengan demikian sebenarnya ia tidak menahan diri atas apapun.

Ada anggapan bunga sebagai imbalan sewa yang didasarkan dari rumusan yang menempatkan posisi rent, wage, dan interest. Rumus ini menunjukkan bahwa padanan rent (sewa) adalah aset tetap dan aset bergerak, sedangkan interest (bunga) padanannya uang. Hal ini tentu tidak tepat karena uang bukan aset tetap, karena itu menuntut sewa uang tidak beralasan.

Islam tidak mengenal konsep time value of money. Islam mengenal konsep economic value of time, artinya yang bernilai adalah waktu itu sendiri. Islam memperbolehkan penetapan harga tangguh-bayar lebih tinggi daripada harga tunai. Zaid bin Ali Zainal Abidin bin Husain bin Ali bin Abi Thalib, cicit Rasulullah Saw. adalah orang yang pertama kali menjelaskan diperbolehkannya penetapan harga tangguh yang lebih tinggi itu sama sekali bukan disebabkan time value of money, namun karena semata-mata ditahannya hak si penjual barang. ${ }^{39}$

Dalam ekonomi Islam economic value of time diterapkan dalam

Transaksi Bisnis, trans. oleh Aini Aryani (Bogor: Ulil Albaab Institute, 2010), h. 200.

${ }^{39}$ Muhammad Syaf'i Antonio, Bank Syariah dari Teori ke Praktik, h. 186. 
lembaga keuangan syariah, sebagai contoh dalam menghitung nisbah bagi hasil di bank syariah. Dalam proses penentuan nisbah ini, return on capital harus diperhitungkan. Return on capital ini tidak sama dengan return on money. Return on capital tergantung kepada jenis bisnisnya dan berkaitan denga sektor ril, sedangkan return on money berkaitan dengan interest rate. Penentuan nisbah bagi hasil harus dilakukan di awal, dan untuk itu digunakan projected return. Jika kemudian ternyata actual return dari bisnis yang dibiayai tidak sama dengan angka dari proyeksinya, maka yang digunakan adalah angka aktual, bukan angka proyeksi. Hal ini menunjukkan bahwa Islam tidak mengenal time value of money. Time mempunyai economic value jika dan hanya jika waktu tersebut dimanfaatkan dengan menambah faktor produksi yang lain, sehingga menjadi capital dan dapat memperoleh return. ${ }^{40}$

\section{Penutup}

Pada dasarnya Islam memandang uang hanya sebagai alat tukar, bukan sebagai barang dagangan (komoditas). Oleh karena itu motif permintaan akan uang adalah untuk memenuhi kebutuhan transaksi (money demand for transaction), bukan untuk spekulasi. Islam juga sangat menganjurkan penggunaan uang dalam pertukaran karena Rasulullah telah menyadar kelemanahan dari saah satu bentuk pertukaran di zaman dahulu yaitu barter (ba’i al-muqayyadah), di mana barang-barang saling dipertukarkan. Konsep time value of money atau juga disebut ekonom sebagai positive time preference menyebutkan bahwa nilai komoditi pada saat ini lebih tinggi nilainya bila dibandingkan di masa mendatang. Time Value of Money sangat terkait erat dengan konsep 'diskonto' yang ada dalam teori modal dan investasi. Secara praktis, digunakan sebagai alat evaluasi proyek maupun keputusan investasi.

Dalam konsep Islam tidak dikenal money demand for speculation. Hal ini karena spekulasi tidak diperbolehkan. Uang pada hakikatnya adalah milik Allah Swt. yang diamanahkan kepada manusia. Oleh karenanya, menimbun uang (dibiarkan tidak produktif) tidak dikehendaki karena

${ }^{40}$ Adiwarman A Karim, Ekonomi Makro Islami, h. 88. 
berarti mengurangi jumlah uang beredar. Dalam pandangan Islam, uang adalah flow concept, karenanya uang harus selalu berputar dalam perekonomian, akan semakin tinggi tingkat pendapatan masyarakat maka akan semakin baik perekonomian. Implikasi konsep Time Value of Money adalah adanya bunga. Sedangkan bunga erat kaitannya dengan riba, dan riba adalah haram sert azulm. Dan agama melarangnya. Sehingga dianggap tidak sesuai dengan keadilan di mana "al-qhumu biqhurni" (mendapatkan hasil tanpa mengeluarkan resiko), dan "al-khraj biladhaman" (memperoleh hasil tanpa mengeluarkan biaya).

Islam tidak mengenal konsep time value of money. Islam mengenal konsep economic value of time, artinya yang bernilai adalah waktu itu sendiri. Islam memperbolehkan penetapan harga tangguh-bayar lebih tinggi daripada harga tunai. Zaid bin Ali Zainal Abidin bin Husain bin Ali bin Abi Thalib, cicit Rasulullah Saw. adalah orang yang pertama kali menjelaskan diperbolehkannya penetapan harga tangguh yang lebih tinggi itu sama sekali bukan disebabkan time value of money, namun karena semata-mata ditahannya hak penjual barang.

\section{Pustaka Acuan}

Antonio, Muhammad Syafi'i. Bank Syariah dari Teori ke Praktik. Jakarta: Gema Insani Press, 2001.

Ahmad, Abu Umar Faruq, and M. Kabir Hassan. "The Time Value of Money Concept in Islamic Finance." American Journal of Islamic Social Sciences 23, no. 1 (2006): 66.

Arifin, Zainul. Dasar-dasar Manajemen Bank Syariah. Jakarta: Alvabeta, 2006.

Achsien, Iggi H. Investasi Syariah di Pasar Modal: Menggagas Konsep dan Praktek Manajemen Portofolio Syariah. Surakarta: Gramedia Pustaka Utama, 2009.

Capra, M. Umar. Masa Depan Ilmu Ekonomi: Sebuah Tinjauan Islam. Jakarta: Gema Insani Press, 2001.

Chandra, M. Jeya, and Michael L. Bahner. "The Effects of Inflation and the Time Value of Money on Some Inventory Systems." International 
Journal of Production Research 23, no. 4 (1985): 723-730.

Chang, Horng-Jinh, Cheng-Hsing Hung, and Chung-Yuan Dye. "A Finite Time Horizon Inventory Model with Deterioration and TimeValue of Money Under the Conditions of Permissible Delay in Payments." International Journal of Systems Science33, no. 2 (2002): $141-151$.

Diwanti, Rela. "Pemikiran Ibnu Rusyd Tentang Qiradh dan Implikasinya dengan Produk Qiradh Pada Bank Riau Syariah Cabang Pekanbaru." PhD diss., Universitas Islam Negeri Sultan Syarif Kasim Riau, 2010.

Datta, T. K., and A. K. Pal. "Effects of Inflation and Time-Value of Money on an Inventory Model with Linear Time-Dependent Demand Rate and Shortages." European Journal of Operational Research 52, no. 3 (1991): 326-333.

Dey, Jayanta Kumar, Shyamal Kumar Mondal, and Manoranjan Maiti. "Two Storage Inventory Problem with Dynamic Demand and Interval Valued Lead-Time Over Finite Time Horizon Under Inflation and Time-Value of Money." European Journal of Operational Research 185, no. 1 (2008): 170-194.

Departemen Agama. Alquran dan Terjemahnya. Semarang: Asy-Syifa, 2000.

Hasan, Ahmad. Mata UangIslami: Telaah Komprehensif Sistem Keuangan Islami. Trans. oleh Saifurrahman Barito Jakarta: PT Raja Grafindo Persada, 2005.

Hou, K-L., and L-C. Lin. "An EOQ Model for Deteriorating Items with Price-and Stock-Dependent Selling Rates Under Inflation and Time Value of Money." International Journal of Systems Science 37, no. 15 (2006): 1131-1139.

Karim, Adiwarman A. Ekonomi Makro Islami. Jakarta: PT Raja Grafindo Persada, 2007.

, Bank Islam: Analisis Figh dan Keuangan. Jakarta: PT Raja Grafindo Persada, 2006.

Khan, M. Fahim. "Time Value of Money and Discounting in Islamic Perspective." Review of Islamic Economics 1, no. 2 (1991): 35-45. 
Lubis, Dian Asriani. "Kepailitan Menurut Ibnu Rusyd dan Perbandingannya dengan Hukum Kepailitan Indonesia." PhD diss., Universitas Islam Negeri Sultan Syarif Kasim Riau, 2011.

Mondal, Madhab, Amit Kumar Maity, Manas Kumar Maiti, and Manoranjan Maiti. "A Production-Repairing Inventory Model with Fuzzy Rough Coefficients Under Inflation and Time Value of Money." Applied Mathematical Modelling 37, no. 5 (2013): 3200-3215.

Muhammad. Manajemen Bank Syariah. Yogyakarta: UPP AMP YKPN, 2005.

, Dasar-dasar Keuangan Islam. Yogyakarta: Ekonosia, 2011.

Manullang, Manginar. Pengantar Teori Ekonomi Moneter. Deli: Deli Pertjetakan \& Toko Buku, 1962.

Mansoori, Muhammad Tahir dan Hendri Tanjung. Kaidah-kaidah Fiqih Keuangan dan Transaksi Bisnis. Trans. oleh Aini Aryani. Bogor: Ulil Albaab Institute, 2010.

Nabhani, Taqyuddin al-. Membangun Sistem Ekonomi Alternatif Persepektif Islam, Cet.VIII. Surabaya: Risalah Gusti, 2009.

Qasim, Abû 'Ubaid al-. Ensiklopedia Keuangan Publik. Trans. oleh Setiawan Budi Utomo. Jakarta: Gema Insani Press, 2009.

Rozalinda. Ekonomi Islam: Teori dan Aplikasinya pada Aktivitas Ekonomi. Jakarta: PT Raja Grafindo Persada, 2014.

Rahman, Afzalur. Doktrin Ekonomi Islam, 2. Yogyakarta: PT. Dana Bhakti Wakaf, 1995.

Rivai, Veithzal dan Andi Buchari. Islamic Economics. Jakarta: PT Bumi Aksara, 2009.

Sarker, Bhaba R., and Haixu Pan. "Effects of Inflation and the Time Value of Money on Order Quantity and Allowable Shortage." International Journal of Production Economics 34, no. 1 (1994): 65-72.

Sarkar, Biswajit, Shib Sankar Sana, and Kripasindhu Chaudhuri. "An Imperfect Production Process for Time Varying Demand with Inflation and Time Value of Money-an EMQ Model." Expert Systems with Applications 38, no. 11 (2011): 13543-13548. 
Shawi, Abdullah al-Muslih dan Shalah Ash-. Fikih Ekonomi Keuangan Islam. Trans. oleh Abu Umar Basyir. Jakarta: Darul Haq, 2004.

Shah, Nita H. "Inventory Model for Deteriorating Items and Time Value of Money for a Finite Time Horizon Under the Permissible Delay in Payments." International Journal of Systems Science 37, no. 1 (2006): 9-15.

Sholihin, Ahmad Ifham. Buku Pintar Ekonomi Syariah. Jakarta: PT. Gramedia Pustaka Utama, 2010.

Shihab, M. Quraish. Tafsir al-Misbah. 15, Cet. 5. Jakarta: Lentera Hati, 2012.

Singh, S. R., Neeraj Kumar, and Rachna Kumari. "Two-Warehouse Inventory Model for Deteriorating Items with Shortages Under Inflation and Time-Value of Money." International Journal of Computational and Applied Mathematics 4, no. 1 (2009): 83-94.

Wee, Hui-Ming, and Sh-Tyan Law. "Replenishment and Pricing Policy for Deteriorating Items Taking Into Account the Time-Value of Money." International Journal of Production Economics 71, no. 1-3 (2001): 213-220.

, "Economic Production Lot Size for Deteriorating Items Taking Account of the Time-Value of Money." Computers \& Operations Research 26, no. 6 (1999): 545-558. 